\title{
Heavy flooding effects on home range and habitat selection of free-ranging Iberian hares (Lepus granatensis) in Doñana National Park (SW Spain)
}

\author{
Francisco Carro \& Ramón C. Soriguer \& J. F. Beltrán \& \\ Ana C. Andreu
}

\begin{abstract}
The Iberian hare Lepus granatensis is a common and abundant species throughout the Iberian Peninsula; however, studies documenting its ecology are scarce. Between August 1996 and September 1997, after a long drought, we studied the effects of a widespread flood on the Iberian hare ecology in ecotone pastures of Doñana National Park. Hares were captured using vertical nets through part of 1996 and 1997. Fourteen adult hares (nine females and five males) were tagged with radiocollars and located by triangulation on a daily basis at least once a week. Habitat use was estimated using a geographical information system. The average home range size was 28 ha for males and 24 ha for females. No significant differences were observed between sexes. Significant differences were observed in the use of scrub areas and in dry pastures. During the dry and wet seasons, males and females were most often located in the pastures of the ecotone, rush stands and scrub. The dense bracken (Pteridium aquilinum) and seaside bulrush (Scirpus maritimus) communities were avoided. These results are the first on the spatial ecology of this species in its native habitat.
\end{abstract}

C ommunicated by: Matt W. Hayward

$\overline{\text { F. Carro }(\star)}:$ R. C. Soriguer $:$ A. C. Andreu

Estación Biológica de Doñana (C. S. I. C.),

Avda Américo Vespucio s/n, Isla de la Cartuja,

41092 Sevilla, Spain

e-mail: pcarro@ebd.csic.es

J. F. Beltrán

Department of Physiology and Zoology, University of Seville, Avda. Reina Mercedes, 6,

41012 Sevilla, Spain
Keywords Lepus granatensis - Iberian hare · Home range . Habitat selection $\cdot$ Iberian Peninsula $\cdot$ Doñana $\cdot$ Flooding

Introduction

The presence of an animal and its spatial distribution is determined by (a) resources distribution (Covich 1976; Emlen and Oring 1977), (b) the presence or absence of other individuals of the same species (Brown and Orians 1970), (c) the availability of appropriate habitat (Johnson 1980; Thomas and Taylor 1990) and (d) the presence and location of predators (Estes 2005; Ripple and Beschta 2004). As the density of animals increases, disputes occur over resources, which forces animals to move towards habitats with fewer resources but less competition (Fretwell and Lucas 1969). However, quite often, spatial displacement is produced when the preferences habitat disappear (or are strongly reduced). These effects are observed after a great snow cover or after a flood (Broekhuizen and Maaskamp 1982; Hewson and Hinge 1990; Wolff 1980).

In this paper, we quantify the effects on the changes of habitat use produced by hazardous climatic events changes like a flood in the Doñana National Park (DNP). Knowledge of home ranges and habitat use in the Iberian Hare is very limited (de la Calzada and Martínez 1994; Rodríguez et al. 1997), and no work has ever studied habitat selection and home range in this endemic Iberian species. Our aim was to document Iberian hare's spatial ecology, including habitat use and habitat selection, in a natural, undisturbed, no-hunted area of Doñana National Park with special attention to the flooding effects. 
Material and methods

Study area

This study was performed in the Doñana National Park (SW Iberian Peninsula; Fig. 1). The climate is Mediterranean sub-humid with mild and unpredictable rainy winters and hot dry summers. Generally, rainfall is concentrated to midspring. A long drought, with a mean annual rainfall less than $402 \mathrm{~mm} /$ year, was observed during the period 1990-1995. An intense rainy season producing flooding was observed from 13 December 1996 to 31 April 1997 (Meteorological Station: Palacio de Doñana). The years 1996 to 1997 were considered very wet, with annual rainfall (above 1,000 mm) vastly exceeding the long-term mean annual rainfall of the area (506 mm, period 1970-1996; Urdiales 1997). In fact, during autumn 1996, rainfall was the 30-year record and was matched by the next year's rainfall again.

The main study area occurred in the ecotone zone between marshland and shrubland (Fig. 1). Two of the most outstanding characteristics of this ecotone are the great diversity of animal species that live there and the fact that in some rainy years, it becomes flooded very quickly. The vegetation of this zone is dominated by the plant associations Scirpetum maritimi and Galio palustris with Juncetum maritimum.
Capture methods and radiomarking

Hares were captured and radio-tracked between August 1996 and September 1997. Hares were caught at night by using a vehicle to drive them into long nets. The sex of all animals was identified by their external genitalia, and they were weighed to determine their ages (Carro 2005). This method of capture does not harm the hares, and many animals can be captured in a short space of time (Keith et al. 1968). A total number of 14 free-ranging hares (five males and nine females) were radio-tracked (Table 1).

Each hare was ear-marked with individually identifiable numbered plastic tags and fitted with a radio-tracking collar of ca. $30 \mathrm{~g}$, less of $1.5 \%$ of body weight of adult hare, equipped with an activity sensor (Wagener radiocollars, Germany) with a life expentancy of 6 to 7 months. Hares were located one to two times a day on daytime and sunrise, at least once a week, depending on the season. Locations were performed by triangulating pairs of fixed stations. The location error estimated from experimental trials was $>10 \mathrm{~m}$. For the home-range analyses, we selected telemetry fixes separated by at least $12 \mathrm{~h}$, in order to avoid any autocorrelation between consecutive locations (Swihart and Slade 1985a, b). An incremental area analysis was carried out plotting the size of home ranges vs. number of locations (Kenward and Hodder 1992). We found that 25

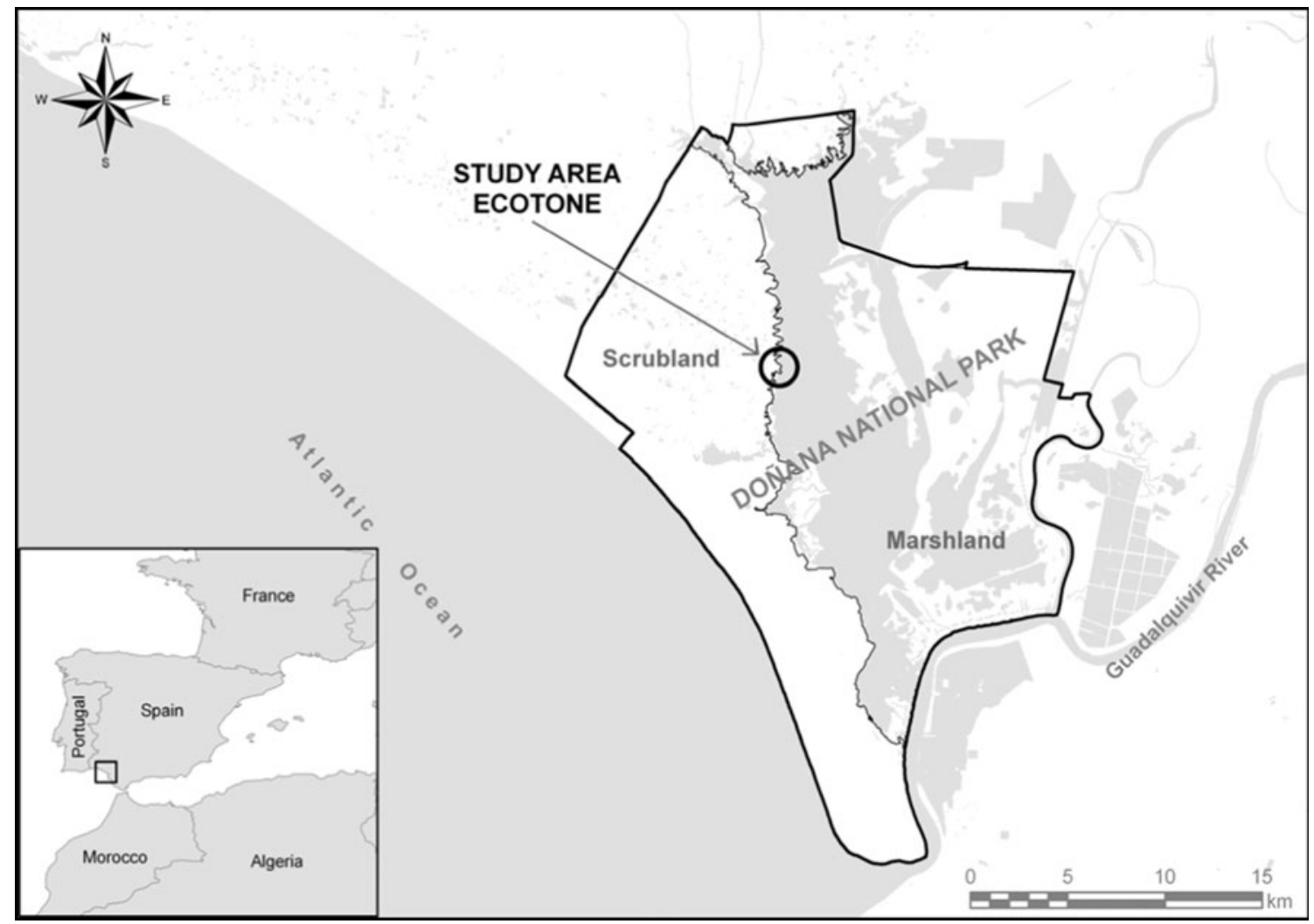

Fig. 1 Study area in the Doñana National Park 
Table 1 Examples of Iberian Hare radiotagged in ecotone of Doñana National Park
Collar emission frequency; Date of capture date of fitting with radio collar; Date of last position date of last position available

\begin{tabular}{llllll}
\hline Collar & Sex & Age & Date of capture & Date of last position & No. of locations \\
\hline 144.613 & F & SA & $12 / 08 / 1996$ & $12 / 12 / 1997$ & 31 \\
144.764 & F & A & $08 / 08 / 1996$ & $12 / 12 / 1997$ & 42 \\
144.564 & F & SA & $08 / 08 / 1996$ & $14 / 12 / 1997$ & 43 \\
144.714 & M & J & $08 / 08 / 1996$ & $09 / 06 / 1997$ & 68 \\
144.690 & F & A & $12 / 08 / 1996$ & $31 / 03 / 1997$ & 35 \\
144.914 & F & A & $12 / 08 / 1996$ & $01 / 04 / 1997$ & 41 \\
144.589 & F & A & $13 / 08 / 1996$ & $20 / 01 / 1997$ & 28 \\
$144.539 a$ & F & A & $12 / 08 / 1996$ & $20 / 01 / 1997$ & 47 \\
144.739 & F & SA & $13 / 08 / 1996$ & $23 / 09 / 1997$ & 108 \\
144.888 & M & A & $04 / 03 / 1997$ & $09 / 06 / 1997$ & 43 \\
144.839 & M & A & $11 / 03 / 1997$ & $28 / 07 / 1997$ & 58 \\
144.789 & F & A & $12 / 03 / 1997$ & $20 / 08 / 1997$ & 54 \\
$144.764 b$ & M & A & $12 / 03 / 1997$ & $06 / 09 / 1997$ & 60 \\
150.080 & M & A & $13 / 03 / 1997$ & $28 / 09 / 1997$ & \\
\hline
\end{tabular}

locations were enough for obtaining a stable estimate of the size of an Iberian hare's home range.

Home range, habitat use and habitat selection

Data were pre-processed with the programme Locate II version 1.3 (Pacer 1990). Calculations for estimating the minimum angular error between the observed angles and the estimation of the location of the animal were carried out by means of a maximum likelihood estimator (Lenth 1981). The sizes of the hares' home ranges were estimated using the programme RANGES V (Kenward and Hodder 1996), the home ranges as expressed by the minimum convex polygon that connected the most far-flung points of the arithmetical average of localisations for each animal (Mohr and Stumpf 1966; Jenrich and Turner 1969), using 90\% of radio localisations thereby excluding peripheral fixes which could be classed as occasional exploratory excursions, to calculate the size of the home range of Iberian hares (Dixon and Chapman 1980; Tapper and Barnes 1986). We used this estimator for facilitating comparison with other data on hares already published.

Habitat use was calculated with a geographical information system (White and Garrod 1990) using the programmes Idrisi (Clark Labs., USA) and Arcview 3.1. Andalusian Government 1:16,000 scale aerial maps from 1997 and 1998 were also used. First, a digital aerial photograph was geo-referenced using the programme Idrisi (Clark Labs. USA). Six classes of vegetation were identified (scrub, rushes, bracken, reeds, dry pasture and pastures in "La Vera", ecotone) and then digitalised and converted into polygons. The percentage of use was calculated as the percentage of the home range lying in each of the different habitats; the availability percentage was taken as the relative presence of each habitat within the total surface area.
In order to test for significant differences between male and female home ranges, the Mann-Whitney U test was applied. Habitat selection was established by means of Ivlev's Index (Ivlev 1961; Garneau et al. 2008; Sidorovich et al 2008), in which the choice of habitat by the species was calculated by the formula:

IES : \% Use - \% Availability = \% Use p \% Availability:

The value of Ivlev's Index varies between +1 , which would represent the exclusive use of that habitat by hares, and -1 , which would indicate a total rejection of that habitat. A value of 0 indicates a neutral selection of the habitat in relation to its percentage presence in the whole area.

\section{Results}

\section{Home range size}

The home range estimated with a minimum convex polygon using $90 \%$ of radio localizations was larger in males (28 \pm $12 \mathrm{ha}$ ) than in females ( $24 \pm 10 \mathrm{ha}$ ) during the whole of the study period, although the difference was not significant (Table 2).

\section{Homes ranges and flooding effects}

The largest home range observed (48 ha) was that of a female in the dry period, which contrasts with the largest observed male home range (36 ha). During the wet season, females also had larger home ranges, with averages of 20 ha as opposed to average male values of 16 ha (Table 2). The differences in 
Table 2 Home ranges of adult Iberian hares in ecotone in southern Spain in two seasons: dry (summer), wet (winter) and home range total

\begin{tabular}{|c|c|c|c|c|c|c|c|c|c|c|c|}
\hline & \multicolumn{5}{|c|}{ Males } & \multicolumn{4}{|c|}{ Females } & \multirow[b]{2}{*}{$\mathrm{S}$} & \multirow[b]{2}{*}{$\mathrm{p}$} \\
\hline & $\mathrm{N}$ & Min. & Max. & $\overline{\mathrm{x}}$ & $\mathrm{S}$ & $\mathrm{N}$ & Min. & Max. & $\overline{\mathrm{x}}$ & & \\
\hline MPC90 Ecotone dry & 5 & 12 & 36.2 & 22 & 8.9 & 9 & 13 & 47.6 & 22 & 12 & ns \\
\hline MPC90 Ecotone wet & 5 & 10 & 23.5 & 16 & 5.6 & 3 & 14 & 25.4 & 20 & 5.5 & ns \\
\hline MPC90 Ecotone Total & 5 & 12 & 40.9 & 28 & 12 & 9 & 13 & 41 & 24 & 10 & ns \\
\hline
\end{tabular}

Min minimum, Max m, $\bar{x}$ average, S standard deviation, MPC90 dry minimum convex polygon with 90\% of radio localisations in dry season, MCP90 wet minimum convex polygon with $90 \%$ of radio localisations in wet season, MPCTotal minimum convex polygon with $90 \%$ of all radio localisations, p signification, ns no significant

home ranges observed in different seasons of the year were also non-significant (Mann-Whitney $\mathrm{U}$ test, $\mathrm{U}=43$; $\mathrm{p}=0.5$ ).

Habitat use and habitat selection

Significant differences between sexes were observed in the use of scrub areas (Mann-Whitney $U$ test $=24 ; \mathrm{p}=0.016$ ) and in dry pastures (Mann-Whitney $\mathrm{U}$ test $=19 ; \mathrm{p}=0.004$ ). In both seasons, males most often used the pastures of the ecotone and then the rushes and scrub. Males only used the dry pastures during the dry season, and no use of the stands of bracken or sedges was observed (Table 3).

Overall, scrubland areas were used more during the wet season by males (Mann-Whitney U test $=4.5 ; p=0.08$ ). No significant differences were observed between the dry and wet seasons other than in the scrub areas, both sexes selected rushes positively (Ivlev's Index: +0.32 for males during the dry season and +0.15 for females in the wet season). Other habitats were actively avoided (negative
Ivlev's Index). Stands of bracken and sedges were never used by either sex. Scrub was also largely avoided, but a small part was sometimes used by males (Table 3 ).

During the wet season, hares moved to higher areas to avoid floods and even occupied areas of scrubland, whereas during the dry season hares moved back towards the marshland and occupied areas and plant communities (for example, reed beds) that were flooded when water levels are high (Fig. 2). Hares thus migrated in the dry period towards areas that became flooded during the wet season and in an opposite direction during the wet season (Table 4).

\section{Discussion}

The hares sex and home range size

We expected to find significant variation in home range sizes between sexes, seasons and habitats. These expectations were
Table 3 Habitat use of adult Iberian hare in the ecotone (Ha) during the wet and dry seasons

$\mathrm{N}$ number of animals studied; Min minimum surface area used of corresponding plant community; Max minimum surface area used of corresponding plant community; Average average surface area used of corresponding plant community; $\overline{\mathrm{x}}$ average; $\mathrm{S}$ standard deviation; p significance level; ns no significant

\begin{tabular}{|c|c|c|c|c|c|c|c|c|c|c|c|}
\hline & \multicolumn{5}{|c|}{ Wet season } & \multicolumn{5}{|c|}{ Dry season } & \multirow[b]{2}{*}{$\mathrm{p}$} \\
\hline & $\mathrm{N}$ & Min & Max & $\overline{\mathrm{x}}$ & $\mathrm{S}$ & $\mathrm{N}$ & Min & Max & $\bar{x}$ & $\mathrm{~S}$ & \\
\hline \multicolumn{12}{|l|}{ Males } \\
\hline Scrub & 5 & 0 & 3.7 & 1.8 & 1.4 & 5 & 0 & 1.3 & 0.3 & 0.6 & ns \\
\hline Rushes & 5 & 0.5 & 4.8 & 3.2 & 2.1 & 5 & 0 & 10.3 & 4.4 & 4.1 & ns \\
\hline Dry pastures & 5 & 0 & 0 & 0 & 0 & 5 & 0 & 2 & 0.5 & 1.0 & ns \\
\hline Bracken & 5 & 0 & 0 & 0 & 0 & 5 & 0 & 0 & 0 & 0 & ns \\
\hline Sedges & 5 & 0 & 0 & 0 & 0 & 5 & 0 & 0 & 0 & 0 & ns \\
\hline Reeds & 5 & 0 & 0 & 0 & 0 & 5 & 0 & 0 & 0 & 0 & ns \\
\hline Pasture in La Vera & 5 & 4.5 & 18.6 & 11.2 & 6.1 & 5 & 10.8 & 23.7 & 16.4 & 4.8 & ns \\
\hline \multicolumn{12}{|l|}{ Females } \\
\hline Scrub & 3 & 0 & 0 & 0 & 0 & 8 & 0 & 0 & 0 & 0 & ns \\
\hline Rushes & 3 & 2.5 & 3.9 & 3.1 & 0.7 & 8 & 0.5 & 7.8 & 3.4 & 3 & ns \\
\hline Dry pastures & 3 & 1 & 2 & 1.6 & 0.3 & 8 & 0 & 6 & 1.4 & 1.8 & ns \\
\hline Bracken & 3 & 0 & 0 & 0 & 0 & 8 & 0 & 0 & 0 & 0 & ns \\
\hline Sedges & 3 & 0 & 0 & 0 & 0 & 8 & 0 & 0 & 0 & 0 & ns \\
\hline Reeds & 3 & 0 & 0 & 0 & 0 & 8 & 0 & 1 & 0.1 & 0.3 & ns \\
\hline Pasture in La Vera & 3 & 10.4 & 21.2 & 15.6 & 5.4 & 8 & 6.5 & 39 & 15.7 & 9.7 & ns \\
\hline
\end{tabular}




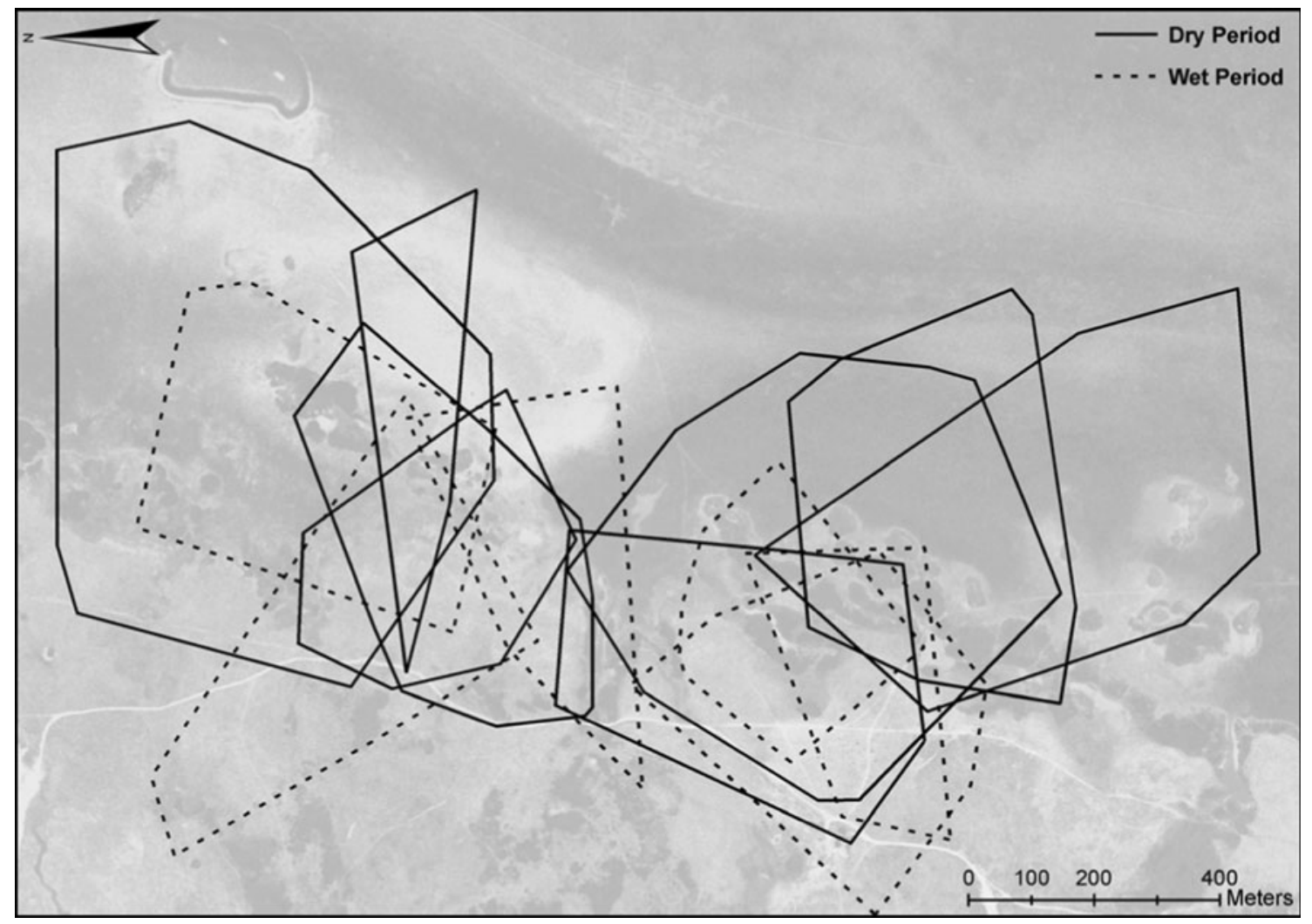

Fig. 2 Habitat use in the dry season and in the wet season in the ecotone of pastures between scrubland (on the left) and marshland (on the right side of the figure). Coordinates UTM. Datum European 1959 (for Spain and Portugal)

based on previous published studies that reported a marked inter- and intraspecific variation in the size of home ranges, which may be explained by factors such as body weight (Harestad and Bunnell 1979), diet and specific energy requirements (McNab 1986).

Previous information on the home ranges of the Iberian Hare is very patchy. Two unpublished reports on hares released for re-introduction, cited by Rodríguez et al. (1997), reported home ranges much larger than those found in this study (Fig. 3). However, a comparison between our data and those published by Rodríguez et al. (1997) is problematical, since these authors worked with hares whose behaviour may have been affected by recent translocation, likely causing them to perform erratic movements. Furthermore, home range size is related to resource availability in large predators reintroduced to Addo Elephant National Park (Hayward et al. 2009). No other data are available for L. granatensis.
Iberian hare home range vs. other hares species

Comparable published data from other hare species (Lepus sp.) show marked variation in home range (Fig. 3), which is according to expected values (Harestad and Bunnell 1979). Adult European brown hares (Lepus europaeus) are 25$35 \%$ larger than adult Mountain hares (Lepus timidus) and so will require larger home ranges. Nevertheless, these values may vary depending on resources available in the habitats in which the hares live. European hares that live in lower-lying areas with better quality trophic resources and a greater variety of croplands and nearby shelter areas have smaller home ranges than those that live in poorer-quality habitats (Tapper and Barnes 1986). Thus, in mosaic areas with an abundance of shrubs, pastures and croplands, hares can shelter in areas of cover and feed in nearby open areas without having to travel great distances.
Table 4 Ivlev's Index of preference for habitat in the Iberian Hare in the ecotone zone of Doñana National Park

WS wet season, DS dry season

\begin{tabular}{llllllll}
\hline & Scrub & Rushes & Dry pasture & Bracken & Sedges & Reeds & Pasture in ecotone \\
\hline Male WS & -0.96 & 0.17 & -1 & -1 & -1 & -1 & -0.69 \\
Male DS & -0.99 & 0.32 & -0.56 & -1 & -1 & -1 & -0.57 \\
Female WS & -1 & 0.15 & -0.05 & -1 & -1 & -1 & -0.59 \\
Female DS & -1 & 0.20 & -0.12 & -1 & -1 & -0.72 & -0.59 \\
\hline
\end{tabular}


Fig. 3 Home ranges and mean body size of hare species as reported in literature. Parkes (1984); Pielowski (1972); Reitz and Leonard (1994); Marboutin and Aebischer (1996); Tapper and Barnes (1986); Kovacs and Búza (1988); Broekhuizen and Maaskamp (1982); Hulbert et al. (1996); Hewson and Hinge (1990); O’ Farrell (1965); Boutin (1984); Carro (2005); Batista and Mexia de Almeida (1996), Farfán et al. (1999) and Virgós et al. (2006). Lam Lepus americanus; Lgr Lepus granatensis; Lti Lepus timidus; Leu Lepus europaeus

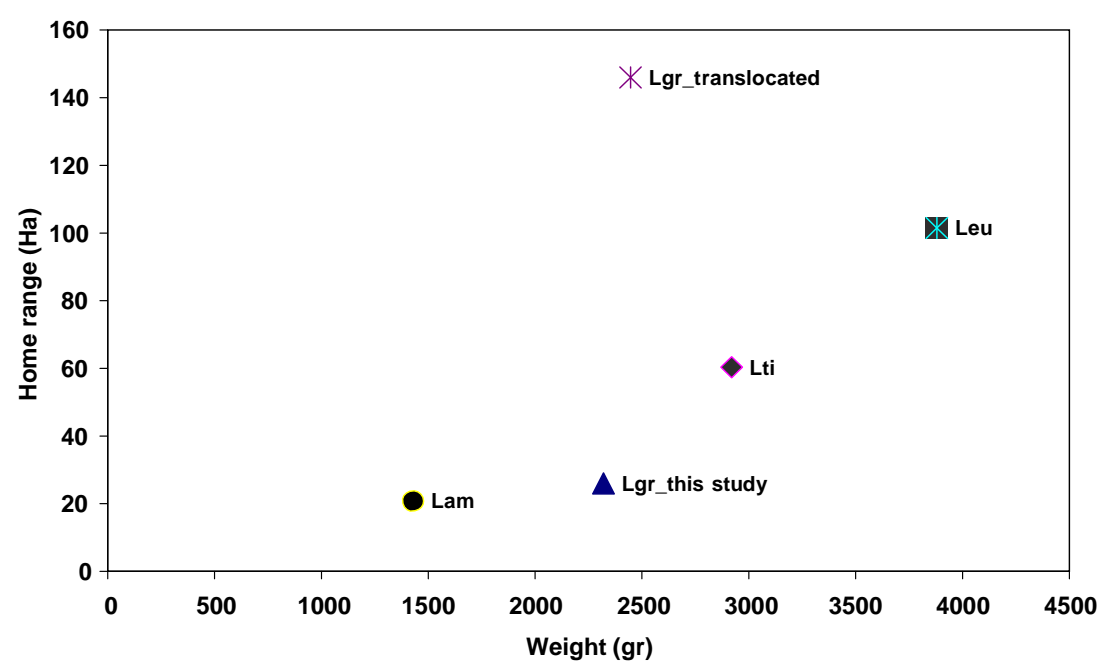

Snowshoe hares L. americanus need large home ranges given their reliance as food sources on heathers, which grow in patches and may even be left inaccessible by snow cover (Hewson 1989). In areas of abundant trophic resources, these hares may even enter into competition with cattle (Hewson 1989). They also need shelter areas and will travel large distances to find them, moving between a variety of feeding habitats and refuge zones that provide shelter from the wind and other meteorological events (Hewson and Hinge 1990).

Mountain and European hare females have smaller home ranges than males. Hewson and Hinge (1990) found that in these species, home ranges were larger during the breeding season, due to the fact, by an inter- and intra-sexual social dominance hierarchy. Male home ranges overlap and males share habitat (Hewson and Hinge 1990). In Doñana, we found no significant differences between home ranges, although female home ranges did tend to be larger. As reported for other species of hares (Hewson 1986), male and female home ranges coincide (both feeding and shelter areas) in both the dry and wet seasons, and as such, no evidence of territorial behaviour exists (Fig. 2). Nevertheless, some conflicts between males that lead to a hierarchy in access to females almost certainly occur.

In DNP, male and female adult Iberian hares differ in habitat use. Our data showed that males occasionally used the cover and other resources of scrubland area while the females never were observed outside of the pasture band. Calzada E de la and Martínez (1994) studied Iberian hares inhabiting another type of ecotone using road censuses. They found that hares have at their disposal all the environments they need to be able to carry out their life cycles and so have smaller home ranges than in the large cereal plains of the Iberian Peninsula. These authors also reported that in cultivated areas, home ranges respond to the cyclical changes that occur in these environments and populations are restructured as they move from unfavourable to more favourable living quarters (de la Calzada and Martínez 1994).

Rodríguez et al. (1997) recorded very large home ranges that included various habitat types, which were chosen depending on requirements, although, as mentioned above, the use of translocated hares makes the interpretation of their data complex. Home range size depends on the types and degree of homogeneity of the habitat (Marboutin and Aebischer 1996) and the time of activity (Reitz and Léonard 1994). Our data agree with the findings of Boutin (1984) for L. americanus which was reduce the home range size depending the optimal diet. Marshlands are secondary habitat partially colonised very dry season and holding high density after long drought periods (Carro 2005).

Iberian hare home range in wet and dry season and flooding effect

The variations in home range sizes between the dry and wet seasons were not significant, although variations did tend to be greatest in the dry season, when part of the ecotone floods in the wet season, the amount of available for the species is reduced and hares are forced to move to higher and drier areas (Table 2). Wolff (1980) found that L. americanus occupied areas that provided refuge (thick forest) in winter and more open areas in summer, which enabled hares to respond to changes in the environment. The macropodid marsupial quokka Setonix brachyurus inhabits swamplands and exhibits a similar movement pattern during seasonal flooding (Hayward et al. 2004).

During rainy years, there is high flooding level of the marshland that few areas can be occupied by Iberian hares. When that happens, Iberian hares move (if they can) from inside of the marshland to reach the marshland border, defined by ecotone pastures. These pastures act as a refuge habitat for 
Iberian hares in the area. If they cannot escape from the flood, individual Iberian hares may find also a refuge in the island of marshland, scattered slightly higher elevations ranging in size from some dozens of metres to a few hectares, where they remain isolated for months, suffering high mortality rates due to predation (Carro et al. 2001, 2002; Carro 2005). Only a few of them, if any, survive the long isolation period. Predation and starvations are the main mortality keys, same for quokkas (Hayward et al. 2005).

Acknowledgements The authors wish to express their gratitude to the staff-especially Jose J. Cháns and J.C Calderón-of the Doñana National Park and Doñana Biological Station for their help with the fieldwork. This study was partially supported by the Plan Andaluz de Investigación (Junta de Andalucía; RNM-118) and Project "Effect of the floods on populations of hares in the Doñana marshland" CICYT (1996-1997). Dr Matt Hayward and two anonymous referees provided insightful comments on versions of this manuscript.

\section{References}

Batista T, Mexia de Almeida L (1996) Resultados das medidas e outras observaçoes em lebres cobradas em provas e caçadas, de 1992 a 1995. Rev Florest 9(1):123-135

Boutin S (1984) Effect of late winter food addition on numbers and movements of snowshoe hares. Oecologia 62:393-400

Broekhuizen S, Maaskamp F (1982) Movement, home range and clustering in the European hare (Lepus europaeus Pallas) in the Netherlands. Z Säugetierkunde 47:22-32

Brown JL, Orians GH (1970) Spacing patterns in mobile animals. Ann Rev Ecol Evol Syst 1:239-262

de la Calzada E, Martínez JF (1994) Requerimientos y selección de hábitat de la liebre mediterránea (Lepus granatensis) en un paisaje agrícola mesetario. Ecología 8:381-394

Carro F (2005) Historia natural de la liebre ibérica (Lepus granatensis Rosenhauer 1856) en el Parque Nacional de Doñana. PhD. Thesis. Department of Animal Biology of the Santiago de Compostela University. Santiago de Compostela

Carro F, Beltrán JF, Pérez JM, Márquez FJ, Iborra O, Soriguer RC (2001) Dinámica poblacional de la liebre ibérica (Lepus granatensis Rosenhaeur, 1856) en el Parque Nacional de Doñana. Galemys 13 (núm. especial):119-126

Carro F, Beltrán FJ, Márquez J, Pérez JM, Soriguer RC (2002) Supervivencia de la liebre ibérica (Lepus granatensis) en el Parque Nacional de Doñana durante un año de fuertes inundaciones. Galemys 14(1):31-38

Covich AP (1976) Analyzing shapes of foraging areas: some ecological economics theories. Annual Review of Ecology, Evolution, and Systematics 7:235-257

Dixon KR, Chapman JA (1980) Harmonic mean measure of animal activity areas. Ecology 61:1040-1044

Emlen ST, Oring LW (1977) Ecology, sexual selection, and the evolution of mating systems. Science 197:215-223

Estes JA (2005) Carnivory and trophic connectivity in kelp forests. In: Ray JC, Redford KH, Steneck RS, Berger J (eds) Large Carnivores and the Conservation of Biodiversity. Island, Washington, DC, pp $61-80$

Farfán MA, Bárcena S, Real R, Lorenzo YFG (1999) Estructura poblacional de la liebre ibérica (Lepus granatensis) a lo largo del ciclo anual. Bases para la gestión cinegética. Resúmenes IV Jornadas SECEM, Segovia, pp. 37
Fretwell SD, Lucas HL (1969) On territorial behaviour and other factors influencing habitat distribution in birds. I. Theoretical development. Acta Biotheor 16:16-36

Garneau DE, Boudreaub T, Keechc M, Post E (2008) Habitat use by black bears in relation to conspecifics and competitors. Mamm Biol 73(2008):48-57

Harestad AS, Bunnell FL (1979) Home range and body weight-a reevaluation. Ecology 60:389-402

Hayward MW, de Tores PJ, Augee ML, Fox BJ, Banks PB (2004) Home range and movements of the quokka Setonix brachyurus (Macropodidae: Marsupialia), and its impact on the viability of the metapopulation on the Australian mainland. J Zool 263:219-228

Hayward MW, de Tores PJ, Augee ML, Banks PB (2005) Mortality and survivorship of the quokka (Setonix brachyurus) (Macropodidae: Marsupialia) in the northern jarrah forest of Western Australia. Wildl Res 32:715-722

Hayward MWGJ, Hayward DD, Kerley GIH (2009) Do fences constrain predator movements on an evolutionary scale? Home range, food intake and movement patterns of large predators reintroduced to Addo Elephant National Park, South Africa. Biodivers Conserv 18:887-899. doi:810.1007/s10531-10008-19452-y

Hewson R (1986) Characteristics of the home range of mountain hares. Mamm Rev 16(3/4):195-196

Hewson R (1989) Grazing preferences of mountain hares on heather moorland and hill pastures. J Appl Ecol 26(1):1-11

Hewson R, Hinge MDC (1990) Characteristics of the home range of mountain hares Lepus timidus. J Appl Ecol 27:651-666

Hulbert IAR, Iason GR, Racey PA (1996) Habitat utilisation in an upland stratified landscape of two lagomorphs with different feeding strategies. J Appl Ecol 33:315-324

Ivlev VS (1961) Experimental ecology of the feeding of fishes. Yale University Press, New Haven

Jenrich R, Turner FB (1969) Measurement of non circular home range. J Theor Biol 22:227-237

Johnson DH (1980) The comparasition of usage and availability measurements for evaluating resource preference. Ecology 61:65-71

Keith LB, Meslow EC, Rongstad O (1968) Techniques for snowshoe hare population studies. J Wildl Manage 32(4):801-812

Kenward RE, Hodder KH (1992) Ranges V - an analysis system for biological location data. Institute of Terrestrial Ecology, Furzebrook Research Station, Wareham, Dorset

Kenward RE, Hodder KH (1996) RANGES V: an analysis system for biological location data. Natural Environment Research Council, Swindon, p 66

Kovacs G, Búza C (1988) Characteristics of the home range of the brown hare (Lepus europaeus Pallas) in a forest and in a large scale cultivated agricultural habitat 1 . Size of the home range. Vadbiologia 88:67-84

Lenth RV (1981) On finding the source of a signal. Technometrics 23:149-154

Locate II (1990) Manual version 1.3. Pacer, Truro

Marboutin E, Aebischer NJ (1996) Does harvesting arable crops influence the behaviour of the European hare Lepus europaeus? Wildlife Biol 2(2):83-91

McNab BK (1986) The influence of food habits on the energetics of eutherian mammals. Ecol Monogr 56:1-19

Mohr CO, Stumpf WA (1966) Comparison of methods for calculating areas of animal activity. J Wildl Manage 30:294-304

O'Farrell TP (1965) Home range and ecology of snowshoe hares in interior Alaska. J Mammal 46(3):406-418

Parkes JP (1984) Home ranges of radiotelemetered hares (Lepus capensis) in a subalpine population in New Zealand: implications for control. Acta Zool Fenn 171:279-281

Pielowski Z (1972) Home range and degree of residence of the European hare. Acta Theriol 9:93-103 
Reitz F, Léonard Y (1994) Characteristics of European hare Lepus europaeus use of space in a French agricultural region of intensive farming. Acta Theriol 39(2):143-157

Ripple WJ, Beschta RL (2004) Wolves and the ecology of fear: can predation risk structure ecosystems? Bioscience 54:755766

Rodríguez M, Palacios J, Martín JA, Yanes T, Martí P, Sánchez C, Navesco MA, Muñoz R (1997) La liebre. Ed. Mundi prensa, Madrid

Sidorovich VE, Polozov AG, Solovej IA (2008) Niche separation between the weasel Mustela nivalis and the stoat M. erminea in Belarus. Wildlife Biology 14(2):199-210

Swihart RK, Slade NA (1985a) Influence of sampling intervals on estimates of home-range size. J Wildl Manage 49:1019-1025

Swihart RK, Slade NA (1985b) Testing for independence of observations in animal movements. Ecology 66:1176-1184
Tapper SC, Barnes RFW (1986) Influence of farming practice on the ecology of the brown hare (Lepus europaeus). J Appl Ecol 23:39-52

Thomas DL, Taylor EJ (1990) Study designs and test for comparing resource use and availability. J Wildl Manage 54:322-330

Urdiales C (1997) Aguas superficiales cantidad de agua. Cap. III. Memoria Anual de Actividades y Resultados Parque Nacional de Doñana, 1996 Gestión e Investigación

Virgós E, Cabezas-Díaz S, Blanco-Aguilar JA (2006) Evolution of life history traits in Leporidae: a test of nest predation and seasonality hypotheses. Biol J Linn Soc 88:603-610

White GC, Garrod RA (1990) Analysis of wildlife radio-tracking data. Academic, San Diego

Wolff JO (1980) The role of habitat patchiness in the population dynamics of snowshoe hares. Ecol Monogr 50(1):111-130 